Hydrology and Earth System Sciences, 5(4), 599-613 (2001) C C EGS

\title{
Effects of forest harvesting on summer stream temperatures in New Brunswick, Canada: an inter-catchment, multiple-year comparison
}

\author{
Charles P.-A. Bourque ${ }^{1}$ and Joseph H. Pomeroy ${ }^{2}$ \\ ${ }^{1}$ Faculty of Forestry \& Environmental Management, University of New Brunswick, P.O. Box 44555, Fredericton, New Brunswick, E3B 6C2, Canada \\ ${ }^{2}$ Environment Canada, Environmental Science Centre, P.O. Box 23005, Moncton, New Brunswick, E1A 6S8, Canada
}

E-mail address for corresponding author: cbourque@unb.ca.

\begin{abstract}
This paper presents a pre- and post-harvest comparison of stream temperatures collected in five neighbouring streams (sub-catchments) over a period of five years (1994-1998). The aim of the study was to determine whether land cover changes from clear cutting in areas outside forest buffer zones (applied to streams $>0.5 \mathrm{~m}$ wide) might contribute to an increase in summer mean stream temperatures in buffered streams downslope by infusion of warmed surface and sub-surface water into the streams. Specific relationships were observed in all five forest streams investigated. To assist in the analysis, several spatially-relevant variables, such as land cover change, mid-summer potential solar radiation, flow accumulation, stream location and slope of the land were determined, in part, from existing aerial photographs, GIS-archived forest inventory data and a digital terrain model of the study area. Spatial calculations of insolation levels for July $15^{\text {th }}$ were used as an index of mid-summer solar heating across sub-catchments. Analysis indicated that prior to the 1995 harvest, differences in stream temperature could be attributed to (i) topographic position and catchment-to-sun orientation, (ii) the level of cutting that occurred in the upper catchment prior to the start of the study, and (iii) the average slope within harvested areas. Compared to the pre-harvest mean stream temperatures in 1994 , mean temperatures in the three streams downslope from the 1995 harvest areas increased by 0.3 to $0.7^{\circ} \mathrm{C}$ (representing a $4-8 \%$ increase; p-value of normalised temperatures $<<0.05)$. The greatest temperature change occurred in the stream that had the greatest proportion of its upper catchment harvested (16.8\%), which also had the highest calculated potential solar loading ( 2749 MJ per stream cell). From the analysis it was determined that the thinning applied to the forest buffer of that stream, with a basal area removal of $\sim 28 \%$, was insufficient to cause significant change in the observed stream temperature. Similar effects were observed following a second harvest in 1997. In general, increases in mean stream temperature coincided with forest harvesting activities outside forest buffers, where conditions promoting stream warming were greatest. In this study, no clear relationship existed between forest buffer strip width (ranging from 30-60 m) and the level of stream warming observed at the monitoring stations.
\end{abstract}

Key Words: terrain attributes, solar radiation, land cover, forest buffers, New Brunswick regulations, spatial modelling, DEM, forest covertypes

\section{Introduction}

Stream water temperature has a clear influence on the chemical, biological, and ecological integrity of streams (Barton et al., 1985; Schlosser, 1991; Stott and Marks, 2000). This influence is expressed primarily through its control of the level of dissolved oxygen in the water (Hoar and Randal, 1971; Davis, 1975; Horne and Goldman, 1994), the development, metabolism, and respiration of aquatic organisms (Mills, 1971; Moore, 1983; Huttener et al., 1988; Eckert, 1988), and environmental toxicity of effluents (Hondzo and Stefan, 1994).
Many factors affect stream-water temperature and related instream processes, including stream surface turbulence, shading, stream size, source water temperature (surface versus groundwater), stream water travel time (Cluis, 1972) and upstream land use conditions (Roth et al., 1996; Stott and Marks, 2000). Field and modelling studies by various researchers, e.g., Brown (1980), Sinokrot and Stefan (1993), Sugimoto et al. (1997), and LeBlanc et al. (1997), demonstrate the relative importance of net energy exchange and the length of exposed streams on diurnal variations in stream temperatures. Small, low-order streams with low 
thermal interia are especially sensitive to excessive warming (Weatherley and Ormerod, 1990), particularly those found in flat to low topographic relief.

Harvesting of forests along watercourses can increase daily maximum and mean water temperatures by as much as 2 to $10^{\circ} \mathrm{C}$ (Brown and Krygier, 1970; Swift and Messer, 1971; van Groenwoud, 1980; Plamondon et al., 1982; Martin et al., 1985; Beschta and Taylor, 1988; Stott and Marks, 2000). A common stream-temperature management practice involves leaving strips of forest on both sides of streams in order to provide shade protection from direct insolation. In New Brunswick (NB), for example, provincial forestry regulations require that $30-\mathrm{m}$ buffer strips on both sides of the stream be used on all mapped, non-intermittent streams $>0.5 \mathrm{~m}$ wide to protect them from excessive radiative warming (Stewart and Comeau, 1996). Lowordered streams, ephemeral channels $<0.5 \mathrm{~m}$ wide and seepage points in upper catchments are ordinarily not buffered because they are usually ill-defined and difficult to detect. Their dense network would furthermore encumber all wood extraction in upper catchments by clear cutting and other low-retention cutting methods.
The objective of this study was to determine whether land cover changes from forest harvesting in areas outside forest buffer zones, applied to streams $>0.5 \mathrm{~m}$ wide, may contribute to the warming of buffered streams by promoting the warming of surface and sub-surface water within the top $10-40 \mathrm{~cm}$ of the unconsolidated portion of the soil as the water travels downslope. To investigate this effect, we assessed forest-harvesting impacts on temperature change in five small NB streams of near similar characteristics, all within $4 \mathrm{~km}$ of each other. In our assessment, we used both field measurements and modelled spatial variables (e.g. insolation, flow accumulation, land cover changes) to conduct spatial comparisons between neighbouring catchments and temporal contrasts between episodes of harvesting. The use of digital elevation models and spatial modelling (introduced later) as a basis for deriving landsurface and other parameters with which to interpret field results provides a new way of investigating the impact of land cover changes on stream quality, that could have otherwise gone undetected.
Hayward \& Holmes Brook Watersheds

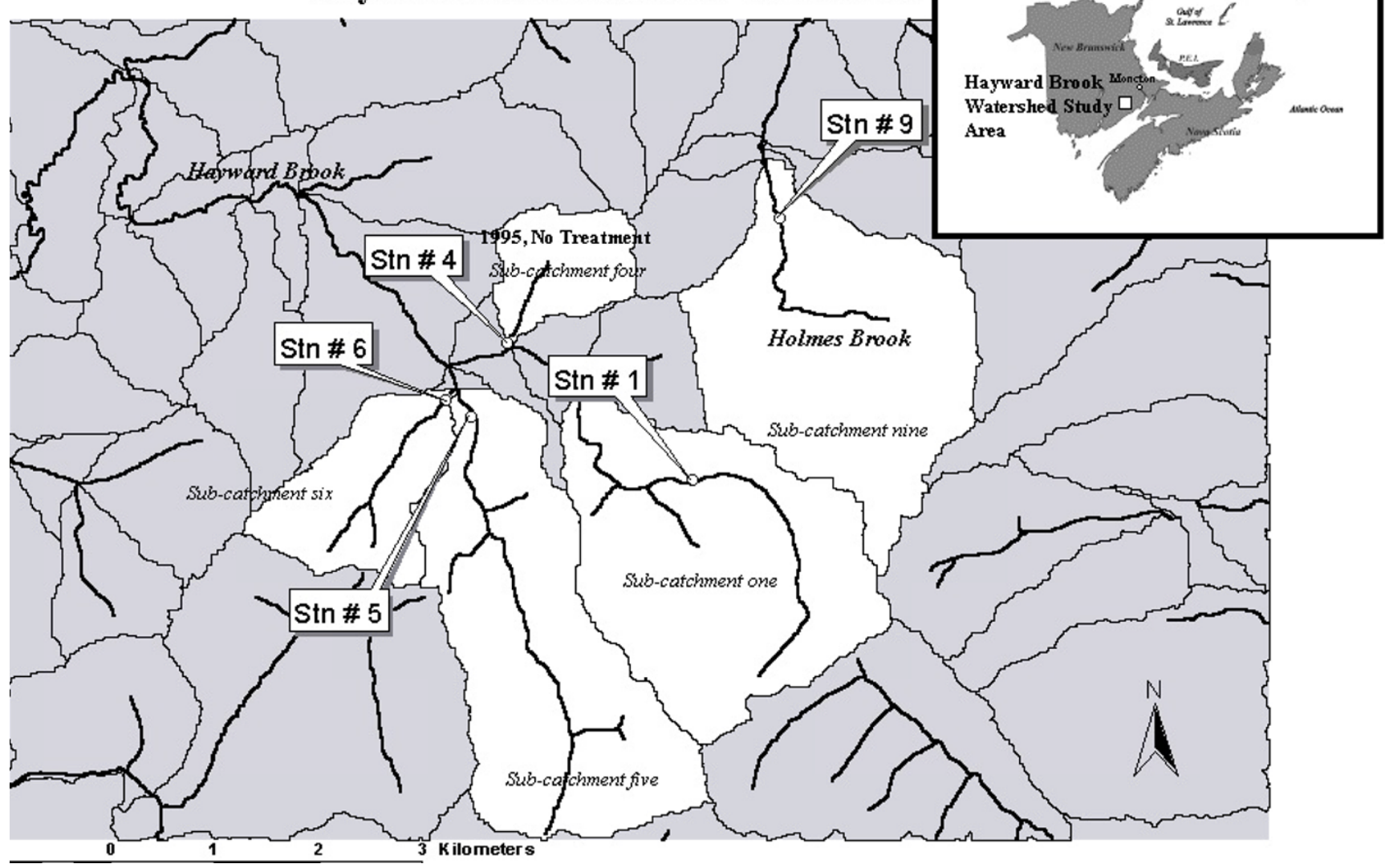

Fig. 1. Indicated are the locations of the Hayward Brook Watershed Study Area (inset) and stream water-monitoring stations. Sub-catchments one, four, five, and six are part of the Hayward Brook watershed and sub-catchment nine is part of the Holmes Brook watershed. Mapped streams are also indicated. 


\section{Study area}

The Hayward Brook Watershed Study (HBWS) is an Environment Canada (EC) and Fundy Model Forest sponsored forest-stream study designed to investigate the ecological responses of low-order forest streams to various forest cutting practices in upstream and riparian-forest locations (Pomeroy et al., 1998). The HBWS site is located within the Fundy Model Forest in the headwaters of the Petitcodiac River basin in southeast NB (centred on $45^{\circ}$ $51^{\prime} \mathrm{N}, 65^{\circ} 08-11^{\prime}$ W; Fig. 1). Of particular interest in the HBWS site are the adjoining Hayward Brook and Holmes Brook watersheds.

The HBWS area has a flat rolling terrain with elevations ranging from about $25 \mathrm{~m}$ at the outlet of Hayward Brook to about $230 \mathrm{~m}$ in the upper portion of the Hayward Brook watershed (Fig. 1). Soils are generally well to imperfectly drained (Fahmy and Colpitts, 1995), on slopes ranging from about $0^{\circ}$ to $45^{\circ}$. The forest cover is classed as mature, mixed Acadian Forest (Rowe, 1972) consisting of a mixture of shade intolerant hardwood and softwood species (e.g. aspen, red spruce, balsam fir and some white and red pine; Pomeroy et al., 1998).

\section{Methodology}

\section{FIELD MEASUREMENTS}

Five automated water-quality stations were installed in selected streams of the HBWS area. Four of the stations, designated by station numbers one, four, five and six (following EC's naming convention), were placed on four separate tributaries of Hayward Brook in March, 1994, and one station (station number nine) on Holmes Brook in the following year (Fig. 1). All five streams were groundwater fed. Stream and streamside characteristics at each of the automatic stations are described in Table 1.

Water-quality measurements taken at each of the stations with Hydrolab ${ }^{T M}$ probes included specific conductance, dissolved oxygen, $\mathrm{pH}$, stream turbidity and stream

Table 1. Stream and streamside characteristics at stream water-quality stations (Fig. 1).

\begin{tabular}{|c|c|c|c|c|c|c|c|}
\hline Station & $\begin{array}{l}\text { Latitude } \\
\text { (xx'xx'xx”) }\end{array}$ & $\begin{array}{l}\text { Longitude } \\
\left(x x^{\circ} x x^{\prime} x x^{\prime \prime}\right)\end{array}$ & $\begin{array}{l}\text { Catchment } \\
\text { area }\left(\mathrm{km}^{2}\right)\end{array}$ & $\begin{array}{l}\text { Average } \\
\text { width (m) }\end{array}$ & $\begin{array}{l}\text { Average } \\
\text { depth (cm) }\end{array}$ & Stream bed ${ }^{a}$ & Forest cover \\
\hline 01 & 455157 & 650927 & 4.2 & $\sim 1$ & $25-50$ & $\begin{array}{l}\text { Large cobbles; } \\
\text { sandy with some } \\
\text { aquatic vegetation } \\
\text { interspersed }\end{array}$ & $\begin{array}{l}\text { Trembling aspen, } \\
\text { red spruce, red \& } \\
\text { white pine }\end{array}$ \\
\hline 04 & 455230 & 651116 & 1.3 & $\sim 1$ & $15-30$ & $\begin{array}{l}\text { Large cobbles; } \\
\text { high sand } \\
\text { component }\end{array}$ & $\begin{array}{l}\text { Mixture of } \\
\text { regenerating } \\
\text { hardwood/softwood } \\
\text { and intolerant hard- } \\
\text { wood-spruce }\end{array}$ \\
\hline 05 & 455218 & 651105 & 6.2 & $2-4$ & $50-100$ & $\begin{array}{l}\text { Large cobbles; } \\
\text { medium sand } \\
\text { component; } \\
\text { plenty of aquatic } \\
\text { vegetation }\end{array}$ & $\begin{array}{l}\text { Intolerant hardwood } \\
\text { and regenerating } \\
\text { hardwood-spruce }\end{array}$ \\
\hline 06 & 455222 & 651116 & 2.2 & $0.5-1.5$ & $30-50$ & $\begin{array}{l}\text { Large cobbles; } \\
\text { medium sand } \\
\text { component, pools } \\
\text { with silt and plenty } \\
\text { of vegetation }\end{array}$ & $\begin{array}{l}\text { Intolerant hardwood } \\
\text { and regenerating } \\
\text { hardwood-spruce }\end{array}$ \\
\hline 09 & 455317 & 650846 & 6.1 & $3-4$ & $70-130$ & $\begin{array}{l}\text { Sandy, large cobbles, } \\
\text { vegetation compo- } \\
\text { nent minor }\end{array}$ & $\begin{array}{l}\text { Spruce-balsam fir and } \\
\text { regenerating } \\
\text { hardwood-spruce }\end{array}$ \\
\hline
\end{tabular}


temperature (accurate to within $0.13^{\circ} \mathrm{C}$; Hydrolab, 1993). Hourly air temperatures measured at an EC weather station about $55-\mathrm{km}$ northeast of the HBWS area, in Moncton, NB ( $46^{\circ} 07^{\prime} \mathrm{N}, 64^{\circ} 41^{\prime} \mathrm{W}$; Fig. 1), were also obtained to facilitate the interpretation of observable trends in summer stream temperatures (June 1-September 30).

\section{DATA REDUCTION AND ANALYSIS}

Occasional gaps in the stream temperature data (representing several days to whole weeks) were filled by means of simple linear equations developed from regression analysis using stream temperature from neighbouring stations with the most complete record as the independent variable. In most comparisons made, accounting for $91 \%$ of all comparisons, the regression equations developed explained over $90 \%$ of the total variation between hourly stream temperatures used; the remaining $9 \%$ of the comparisons had $>88 \%$ of the variability explained. Daily and summer temperature averages were subsequently calculated from these data, as well as from the air temperature data obtained from the Moncton weather station.

The daily average temperatures from Moncton and the water-quality stations on the "non-control" streams were subsequently normalised by dividing their values on a dayby-day basis by the corresponding daily stream temperatures from the "control" stream, which happened to be different for the two harvesting periods (i.e. 1994-1997; 1997-1998). In the first harvesting period, stream four served as the "control", while in the second period (1997-1998), stream five was used. Normalisation of stream temperatures was done to take into account the inter-catchment and interannual variability in the data, permitting for more meaningful comparisons to be made between pre- and postharvest conditions.

\section{FOREST HARVESTING}

Prior to the 1995 harvest, approximately one-fifth (21\%) of the area of sub-catchment four (all within the upper catchment, well above the main branch of stream four; Fig. $2 a$ ) and less than $1 \%$ and $5 \%$ of the total upper drainage area of sub-catchments five and nine had been clearcut in the ten years before the start of this study (column 2 of Table 2; Fig. 2a). Forest buffer strips were generally not used in any of the upslope areas, unless the streams in those areas

Table 2. Forest harvesting and site amendments before and after 1994 in the HWB and HB sub-catchments; compiled from recent aerial photographs, GIS forest inventory datasets, and personal communication with Fundy Model Forest personnel.

\begin{tabular}{|c|c|c|c|c|c|c|c|}
\hline $\begin{array}{l}\text { Sub- } \\
\text { catchment }\end{array}$ & $\begin{array}{l}\text { 1984-1994 } \\
\text { Land } \\
\text { Harvested }^{b}\end{array}$ & $\begin{array}{l}\text { Time of } \\
\text { Treatment }\end{array}$ & $\begin{array}{l}\text { Treatments } \\
\text { Applied }^{c, d}\end{array}$ & $\begin{array}{l}\text { 1994-1998 } \\
\text { Land Area } \\
\text { Harvested } \\
\text { (ha) }\end{array}$ & $\begin{array}{l}\text { Volume } \\
\text { Extracted } \\
\left(\mathrm{m}^{3)}\right.\end{array}$ & $\begin{array}{l}\text { Buffer } \\
\text { Strip Width } \\
\text { (m) }\end{array}$ & $\begin{array}{l}\% \text { Thinning } \\
\text { in Buffer } \\
\text { Strips }\end{array}$ \\
\hline 01 & 0.0 & $\begin{array}{l}\text { Spring- } \\
\text { summer, } \\
1995\end{array}$ & $\mathrm{SW}, \mathrm{CC}, \mathrm{S} / \mathrm{P}$ & $\begin{array}{l}150.3 \\
\left(16.8^{b}\right)\end{array}$ & 14180 & $\begin{array}{l}\text { Variable, } \\
30 \text { to } 60\end{array}$ & 28 \\
\hline 04 & 21.0 & Fall, 1997 & $\mathrm{CC}$ & $\begin{array}{l}33.4 \\
(25.7)\end{array}$ & 6055 & 60 & 0 \\
\hline 05 & 0.9 & $\begin{array}{l}\text { Spring- } \\
\text { summer, } \\
1995\end{array}$ & $\mathrm{CC}, \mathrm{S} / \mathrm{P}$ & $\begin{array}{l}39.2 \\
(3.2)\end{array}$ & 7290 & 30 & 0 \\
\hline 06 & 0.0 & $\begin{array}{l}\text { Spring- } \\
\text { summer, } \\
1995\end{array}$ & $\mathrm{CC}, \mathrm{S} / \mathrm{P}$ & $\begin{array}{l}42.2 \\
(15.1)\end{array}$ & 6038 & 30 & 0 \\
\hline 09 & 4.4 & $\begin{array}{l}\text { Spring } \\
\text {-summer, } \\
1995\end{array}$ & $\mathrm{SW}, \mathrm{CC}, \mathrm{S} / \mathrm{P}$ & $\begin{array}{l}62.4 \\
(11.4)\end{array}$ & 7760 & 60 & 0 \\
\hline \multicolumn{8}{|c|}{ b $\%$ of total catchment area } \\
\hline \multicolumn{8}{|c|}{$\begin{array}{l}{ }^{\mathrm{c}} \mathrm{SW} \text { : shelterwood cut; CC: clear cut } \\
{ }^{\mathrm{d}} \mathrm{S} / \mathrm{P} \text { : sites were scarified in September of 1995, either with a barrel and chain assembly or with a Marden roller; all sites } \\
\text { were re-planted in } 1996\end{array}$} \\
\hline
\end{tabular}




\section{Before 1995}

a)

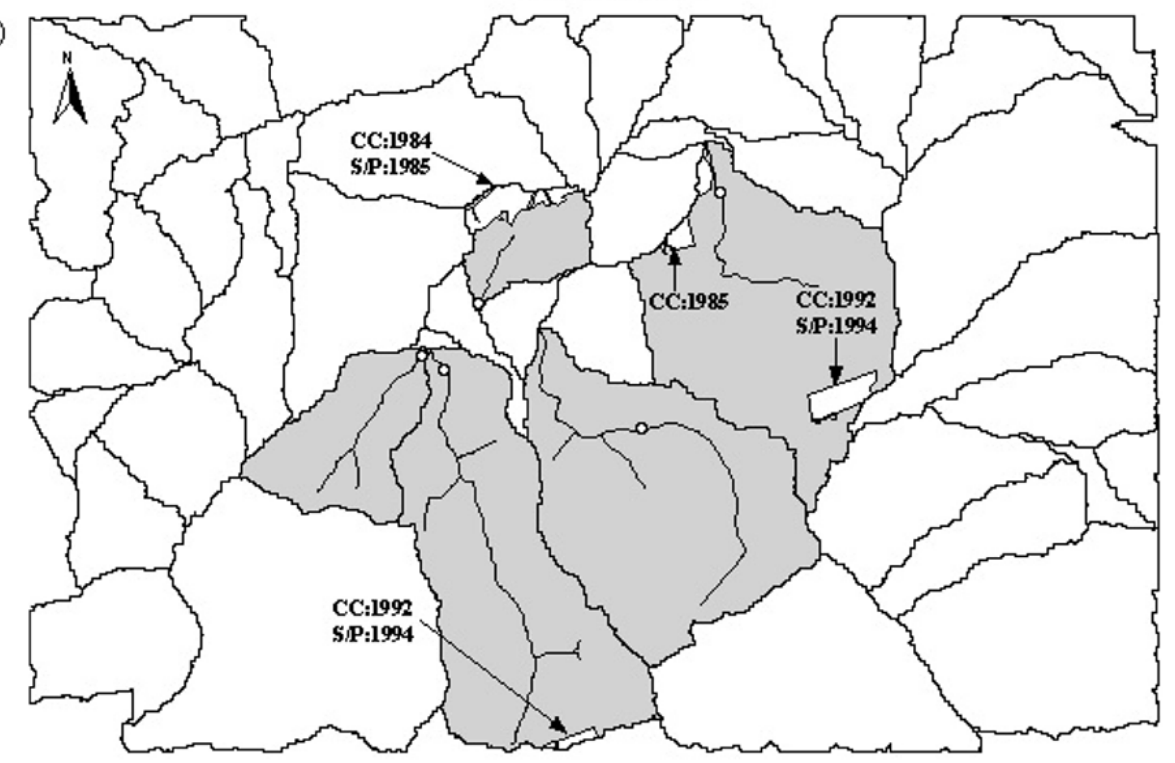

1995

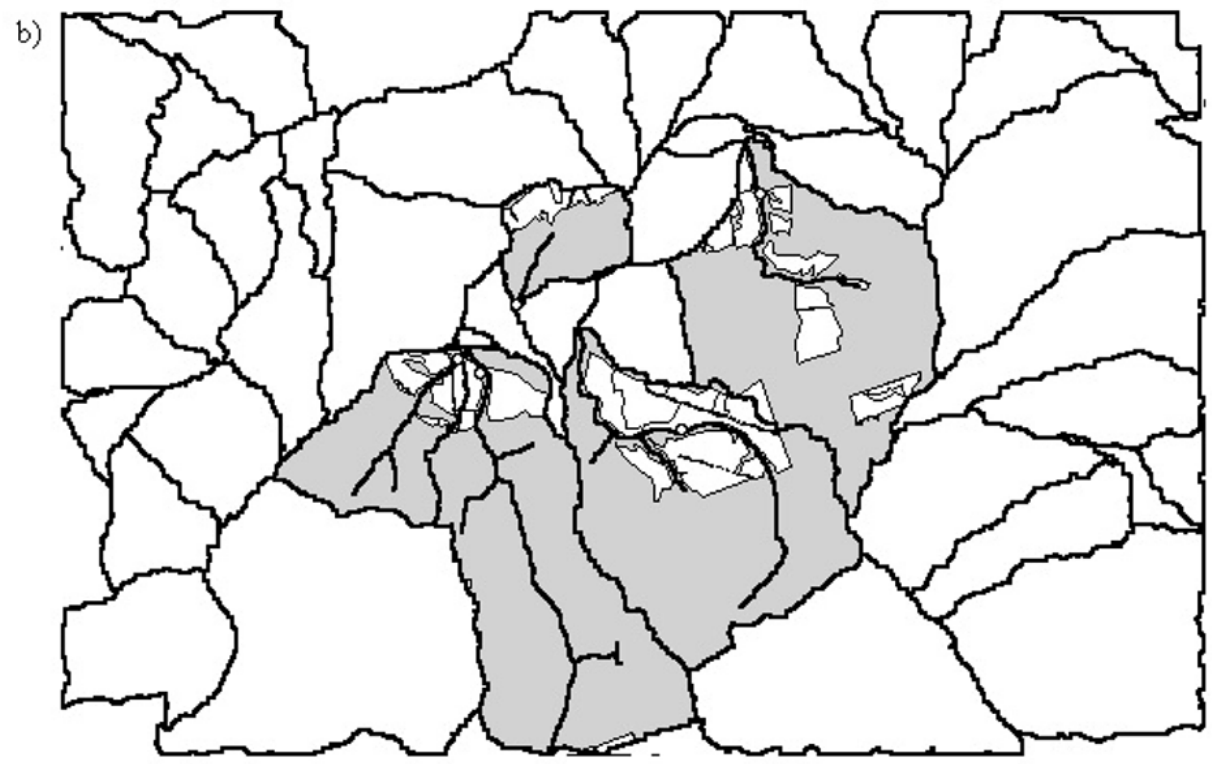

Fig. 2. Extent and location of harvesting that took place during the ten years before the start of the study (a) and during the June-September period in 1995 (b). Cut blocks are shown as white polygons in a predominantly gray background. Year of harvesting (CC) and replanting $(S / P)$ of the sites cut before 1995 are indicated.

were determined to be wider than $0.5 \mathrm{~m}$. Most of the areas harvested during this ten-year period were replanted. Site preparation before replanting usually included the use of a barrel and chain assembly or a Marden roller (pers. comm., Fundy Model Forest personnel, 2001). The approximate years of cutting and replanting of the upslope sites cut before 1994 is specified in Fig. 2a.

During the late spring to late summer (June 1st-September 1st) period in 1995, four of the five sub-catchments were treated with some level of harvesting (see Fig. 2b). As in the previous ten years, forest buffer strips were not commonly used upslope. Buffer strips were used for the most part along the four main streams and the occasional tributary to these streams (Fig. 2b). All harvested blocks were replanted in May-June of the following year. Unharvested sub-catchment four was used as a "control" for the 1994-1997 period.

In the fall of $1997,26 \%$ of the area of sub-catchment four 
was clearcut after September 30th. Again, no forest buffers were used above the main stream (Fig. 3). The four subcatchments harvested in 1995 were not harvested during the 1996-1998 period. For the 1997 to 1998 -harvest period, uncut sub-catchment five was used as the "control".

Buffer strips applied along the main streams during the 1995 and 1997 harvests varied in width (Figs. 2, 3). Thirtymetre buffer strips were used adjacent to the cut areas in the case of streams five and six, and 60-m buffers in the case of streams four and nine. Along stream one, buffer strip widths were varied between 30 to $60 \mathrm{~m}$ depending on the slope of the adjacent land (Krause, 1998); the wider strips were generally reserved for the steeper areas. Basal areas in the buffer strips along stream one were subsequently thinned from an average of about $25 \mathrm{~m}^{2} \mathrm{ha}^{-1}$ to about $18 \mathrm{~m}^{2} \mathrm{ha}^{-1}$ (Krause, 1998).

Harvesting techniques used during the 1995 and 1997 harvests included the shelterwood and clear cutting method.
Forest-cover differences between fully cut and shelterwood cut areas were generally small. Shelterwood cutting allowed for some trees to be left onsite (in this case, primarily white pine), but the level of extraction applied was sufficiently high ( $>80 \%$ of standing timber) that virtually no difference existed in the amount of shade protection provided to the ground. Information relevant to the 1995 and 1997 harvesting operations is summarised in columns $3-8$ of Table 2.

\section{MODELLED QUANTITIES}

\section{Land-surface characterisation}

Critical to the analysis of stream temperature was the digital elevation model (DEM) of the HBWS area. It was from this information that all terrain attributes, sub-catchment insolation and locations of non-mapped, low-order and

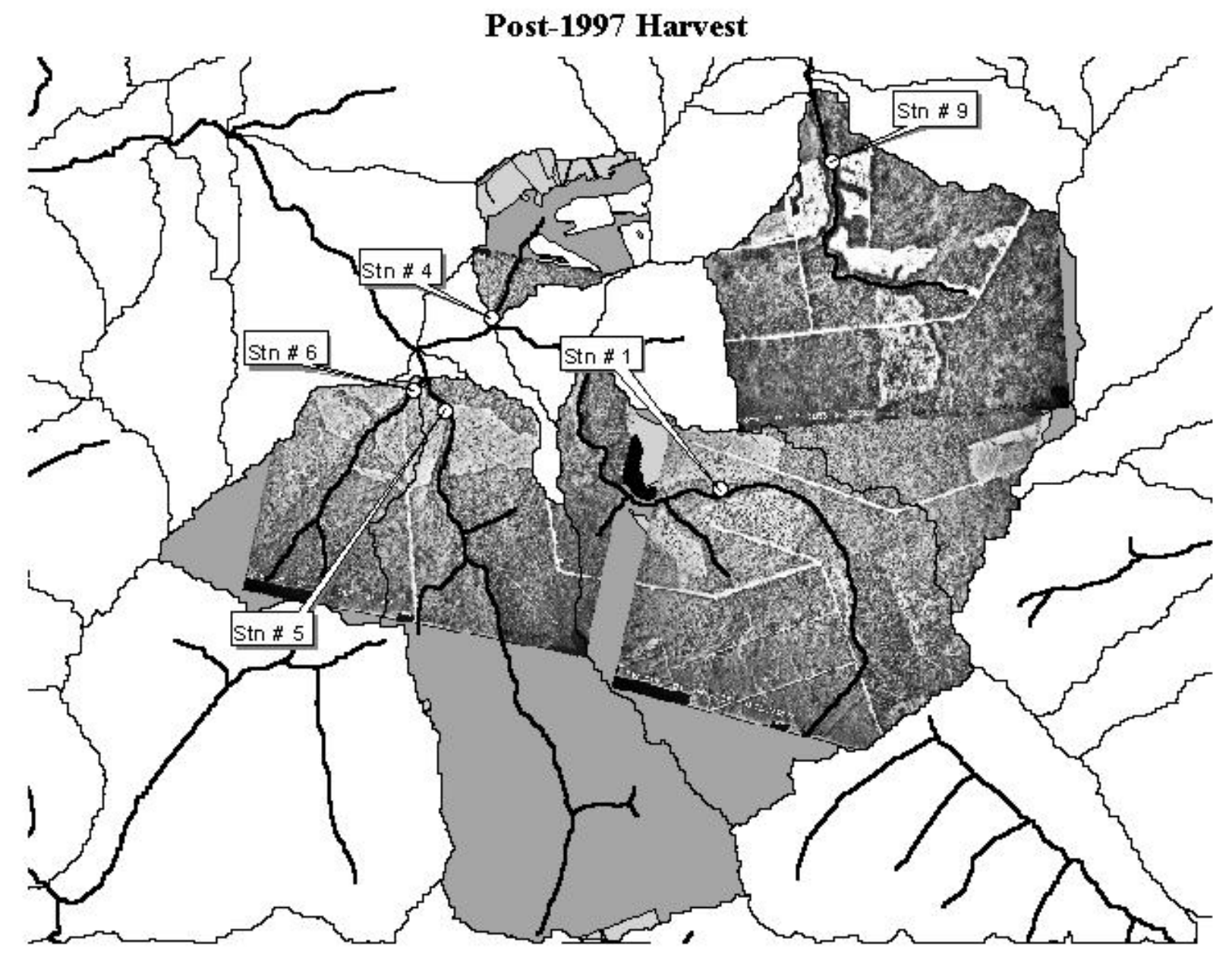

Fig. 3. Land-cover conditions following the 1997 harvest in sub-catchment four. Underlain are aerial photographs of parts of the Hayward Brook and Holmes Brook watersheds, illustrating some of these harvested areas as light-gray angular patches in a predominantly dark-gray background. White lines on the aerial photographs delineate the roads. Areas in sub-catchment four harvested in the fall of 1997 are indicated as white polygons to the right of stream four. 
ephemeral streams $(<0.5 \mathrm{~m}$ wide $)$ were determined. The DEM was constructed by photogrammetric methods from 1:10000 aerial photographs collected as part of the Maritime Provinces Land Registration and Information Services program (NBGIC, 1997), and consisted of a 10-m resolution $1212 \times 788$ rectangular grid generated with the Inverse Distance Weighing (IDW) subroutine in $\mathrm{ArcView}^{\mathrm{TM}}$. Spatial information derived from the DEM critical to this study included (i) slope angle; (ii) slope orientation (aspect); (iii) flow accumulation; (iv) stream network, including ephemerals and other non-mapped stream segments $<0.5 \mathrm{~m}$ wide; $(v)$ potential incoming solar radiation; and $(v i)$ stream integrations of potential solar radiation and slope.

Land cover changes during 1994-1998 were assessed using current aerial photographs and a 1999-updated GISbased forest inventory dataset obtained from the Fundy Model Forest. Scanned images of the aerial photographs were brought in $\mathrm{ArcView}^{\mathrm{TM}}$, with Image Analysis ${ }^{\mathrm{TM}}$ installed, for rectification and for cross validating the GIS inventory dataset (Fig. 2, 3).

\section{Spatial variables}

Slope and aspect: DEM point-calculations of slope $(\Psi)$ and aspect $(\Theta)$ were based on the centred, finite difference approach described in Bourque and Gullison (1998) and by others, such as Moore (1993), and Gallant and Wilson (1996), i.e.

$$
\Psi_{i, j}=\tan ^{-1}\left\{\left[\left(\frac{z_{i+1, j}-z_{i-1, j}}{2 \Delta s}\right)^{2}+\left(\frac{z_{i, j+1}-z_{i, j-1}}{2 \Delta s}\right)^{2}\right]^{1 / 2}\right\}
$$

and

$$
\Theta_{i, j}=90\left(\frac{z_{i+1, j}-z_{i-1, j}}{\left|z_{i+1, j}-z_{i-1, j}\right|}\right)-\tan ^{-1}\left(\frac{z_{i, j+1}-z_{i, j-1}}{2 \Delta s} / \frac{z_{i+1, j}-z_{i-1, j}}{2 \Delta s}\right)
$$

where $z$ represents elevation, and $\Delta$ s the DEM resolution. Subscripted notation " $i+1, j$ " and " $i-1, j$ " above refer to DEMgrid points to the $\mathrm{E}$ and $\mathrm{W}$ of grid point " $i, j$ ", and subscripts " $i, j+l$ " and " $i, j-l$ " to the grid points to the $\mathrm{N}$ and $\mathrm{S}$ of grid point " $i, j$ ".

Flow accumulation: Estimates of flow accumulation were based on the deterministic eight-node, D8, flow direction algorithm developed by O'Callaghan and Mark (1984). The algorithm addresses the flow of water from a grid point to one of eight potential directions coinciding with the gradient of steepest descent, i.e.

$$
\text { Flow Direction }=2^{k-1}
$$

with

$$
\mathrm{k}=\max \left(\frac{\mathrm{z}_{\mathrm{i}, \mathrm{j}}-z_{k}}{\phi(k) \Delta s}\right)
$$

where $\phi(k)=1$ for $\mathrm{N}, \mathrm{E}, \mathrm{S}$ and $\mathrm{W}$ neighbours, and $\phi(k)=$ $2^{1 / 2}$ for NE, SE, SW and NW neighbours (Moore et al., 1993). Flow accumulation represents the total upslope area that contributes (drains) water to a particular grid cell either as a cumulative cell count or total land surface drainage area.

This simple algorithm often yields flow lines parallel to one another ("the herring bone effect"), particularly in nonrugged terrain (Fairfield and Leymarie, 1991 and CostaCabral and Burges, 1994). The method is known for its inability to model flow dispersion or catchment expansion in low relief areas (Moore, 1993; Gallant and Wilson, 1996). Although there were other flow accumulation methodologies available that produce more realistic-looking drainage networks in non-rugged terrain (e.g. the DEMON approach of Costa-Cabral and Burges, 1994), the D8 algorithm was considered adequate for the current application as it provided a simple framework for calculating stream-length (line) integrations of spatial variables like solar radiation and slope (addressed below), and possibilities of flow dispersion in the HWBS area were small.

Before proceeding with the flow accumulation calculations, the DEM needed a level of pre-processing. This involved removing false pits (Jenson, 1991), as well as "forcing" the mapped stream network (GIS line feature) on the DEM by increasing non-stream grid elevations by a specified uniform amount (Olivera et al., 1998). This "forcing" of the DEM this way forced modelled third- and higher-order streams to be correctly positioned within the DEM grid. Location of the low-ordered, unmapped (i.e., ephemeral) streams were based on the flow accumulation calculations applied to the raised portion of the DEM.

Stream network: Stream network delineation was determined by providing a minimum number of DEM-grid cells or threshold area, which was judged to drain directly into a stream.

All pre-processing, flow accumulation and stream network delineation functions were carried out by means of the precompiled ArcView ${ }^{\mathrm{TM}}$ extension (CRWR-PrePro03) available through the Center for Research in Water Resources at the University of Texas, Austin (Olivera et al., 1998). The stream and watershed delineation capabilities of the CRWR software were first used to generate the watershed map displayed in Fig. 1.

Potential solar radiation: Prediction of potential cloud free solar radiation for a typical mid-summer day (e.g. July 15th) was obtained with the LanDSET (Landscape 
Distribution of Energy, Soil moisture, and Temperature) model of Bourque and Gullison (1998) as an index of solar heating across sub-catchments. The model provided hourly predictions of incoming solar radiation that were integrated to give a daily total (Bourque et al., 2000). Solar radiation values generated were spatially modified to account for topographic effects resulting from land surface variations in slope, aspect, horizon angle, skyview and terrain configuration factors (Dozier et al., 1981; Dubayah et al., 1990; Dubayah and Rich, 1996; Bourque and Gullison, 1998).

In this study, modelled incoming solar radiation was not adjusted for cloudiness effects because average cloud cover was predicted to be roughly uniform over the relatively small study area $\left(\sim 30 \mathrm{~km}^{2}\right)$. Also, it was its relative distribution over the land surface that was of primary interest to the researchers.

No effort was made to estimate below-canopy light conditions in this study. As an index of below-canopy conditions, we made the assumption that the large-scale distribution of below-canopy light, although present in diminished quantities, mirrored approximately that of the above-canopy light. In making this assumption, we made below-canopy light regimes implicitly a function of topographic position. On large spatial scales this assumption is justifiable. Forests on south-facing slopes, for example, due to their southerly exposure and alignment of their canopy openings to the incoming light, generally let more sunlight to the forest floor over the course of a day than in forests of equal stock on east-, west- and north-facing aspects (Molga, 1962). Local variations in sunlight penetration in these forests due to local variations in crown spacing, configuration and gap shape, which in some landscapes can be exceedingly high, should have marginal influence at the larger scales because of their inclination to cancel out over large areas. Large forest openings (e.g. > several hectares) resulting from natural or human disturbance, unlike smaller openings ( $<$ several tens to hundreds of $\mathrm{cm}$ ), should have discernible impact at the landscape scale.

Line integrations: Calculation of potential solar radiation loading and mean hydraulic gradient along the stream networks was based, in part, on line integrations of potential solar radiation and slope. The calculation was approached in a manner similar to what was described earlier for flow accumulation. Rather than dealing with individual cell counts and contributing areas as in the case of flow accumulation, the application provides a cumulative account of the values of each of the variables, increasing gradually in the direction of steepest descent. Mean slope for the subcatchments was subsequently calculated by dividing the line integration of slope by the flow accumulation cell count determined at each water-quality station (Fig. 1).

\section{Results and discussion}

MODELLED SUB-CATCHMENT ATTRIBUTES

Figure 4a provides the modelled stream network for the Hayward Brook and Holmes Brook catchments. The black meandering lines within the five sub-catchments provide the actual field-verified positions of the streams. The lighter, gray-coloured lines joining the main streams represent the non-mapped (modelled) low-order and ephemeral, seepage streams $<0.5 \mathrm{~m}$ wide. Note that the small, low-order streams repeatedly intersect the harvested areas. Total contributing (catchment) area upstream of the stations is variable (Table 1), with the largest stream network of sub-catchment five draining about $6.2 \mathrm{~km}^{2}$ of land surface, and the smallest of sub-catchment four about $1.3 \mathrm{~km}^{2}$.

Figure $4 \mathrm{~b}$ provides the spatial distribution of one-day total potential solar radiation (in $\mathrm{MJ} \mathrm{m}^{-2}$ ) for the same area. As expected, potential solar radiation is modelled to be greatest on south-facing aspects, shown in white to light-gray colours, and least on north-facing aspects, shown in darkgray to black colours. One-day total potential solar radiation (for July 15th), under assumptions of zero light attenuation, is greatest for sub-catchment four with $2745 \mathrm{MJ}$ per stream cell $\left(10 \times 10 \mathrm{~m}^{2}\right)$ or about $3.616 \times 10^{7} \mathrm{MJ}$, and least for subcatchment five with $2710 \mathrm{MJ}$ per stream cell; or about 1.672 $\times 10^{8} \mathrm{MJ}$ for the entire sub-catchment (Table 3). From these results and those in Table 3 (i.e. column 2), preliminary ordering of the streams with respect to their anticipated level of warming from direct irradiance places stream four as the warmest, followed by streams nine, six, one, and five; stream five being the coolest overall. Visual inspection of the graphed stream temperatures across the 5 years (Fig. 5), consistently puts stream four and then stream nine as the two warmest streams, and streams six, five, and one as the least warmest.

\section{PRE-1995 HARVEST}

It was not surprising to see stream four as being the warmest (Fig. 5), given the stream's southerly orientation and the large cutovers in its upper catchment dating to the 1984 harvest (Table 2 and Fig. 2a). Although the harvested areas have since been planted, the stocking level applied and the amount of plant growth since planting (c. 1985) have been insufficient to provide adequate shade protection to the surface water present and exposed forest floor (and thus the sub-surface water) within these areas. Warming conditions in these harvested areas have the potential to be significant on account of the total solar radiation reaching the ground 
a) Stream network

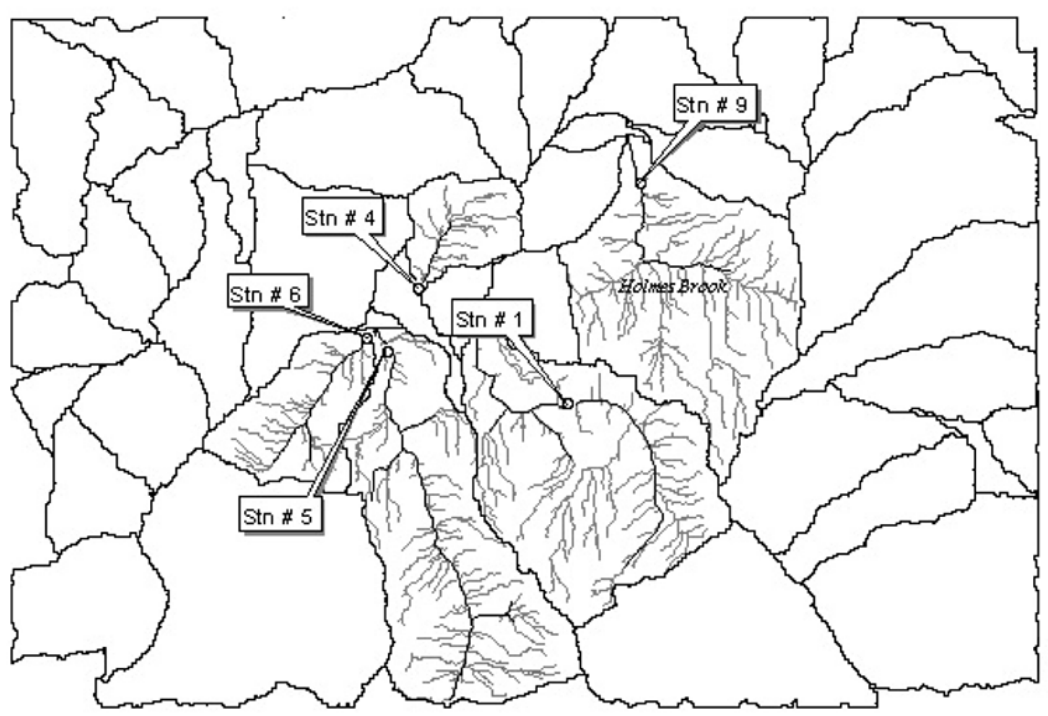

b) Solar radiation $\left(\mathrm{MJ} \mathrm{m}^{-2}\right)$
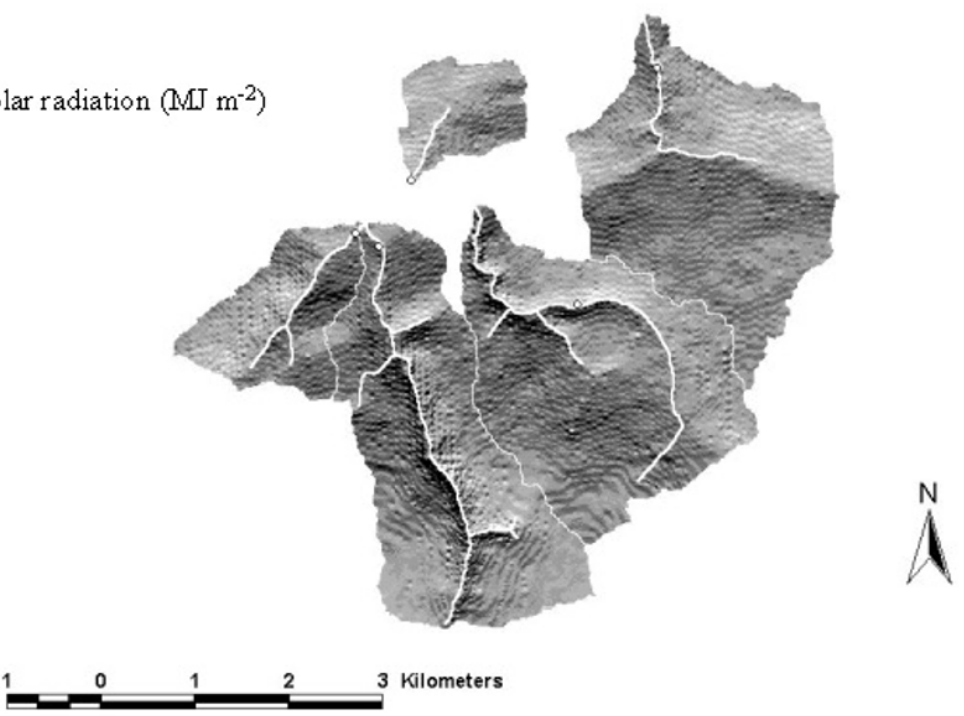

Fig. 4. Modelled stream network (a) and one-day distribution of total potential solar radiation (b) in the Hayward Brook and Holmes Brook watersheds. The dark stream segments in (a) are based on actual mapped streams (the same as in Fig. 1). The finer stream segments branching off the mapped streams are based on modelled flow accumulations and represent the low-order, ephemeral streams, and seepage points in the upper catchment. The dark grays and blacks in (b) represent low insolation values $\left(\sim 16.9 \mathrm{MJ} \mathrm{m}^{-2}\right)$ and the light grays and whites, high insolation values $\left(\sim 29.3 \mathrm{MJ} \mathrm{m}^{-2}\right)$.

$\left(\sim 2772 \mathrm{MJ}\right.$ per cell of exposed ground, or about $7.67 \times 10^{4}$ MJ) and the presence of low mean hydraulic gradients $\left(\sim 2.9^{\circ}\right.$, based on a stream-network integration of slopes within the harvested area). Low hydraulic gradients serve to reduce active drainage of both the surface and sub-surface water, permitting the water to warm even further as it makes its way downslope.
Stream nine was most likely the second warmest stream because of the amount of insolation it received during the summer. Total catchment-wide stream irradiation over one day amounted to about $1.671 \times 10^{8} \mathrm{MJ}$, or about $2729 \mathrm{MJ}$ per stream cell (Table 3 ). Total insolation within the harvested areas in the sub-catchment (accounting for about $4 \%$ of the total land area, Table 2) was calculated to be 

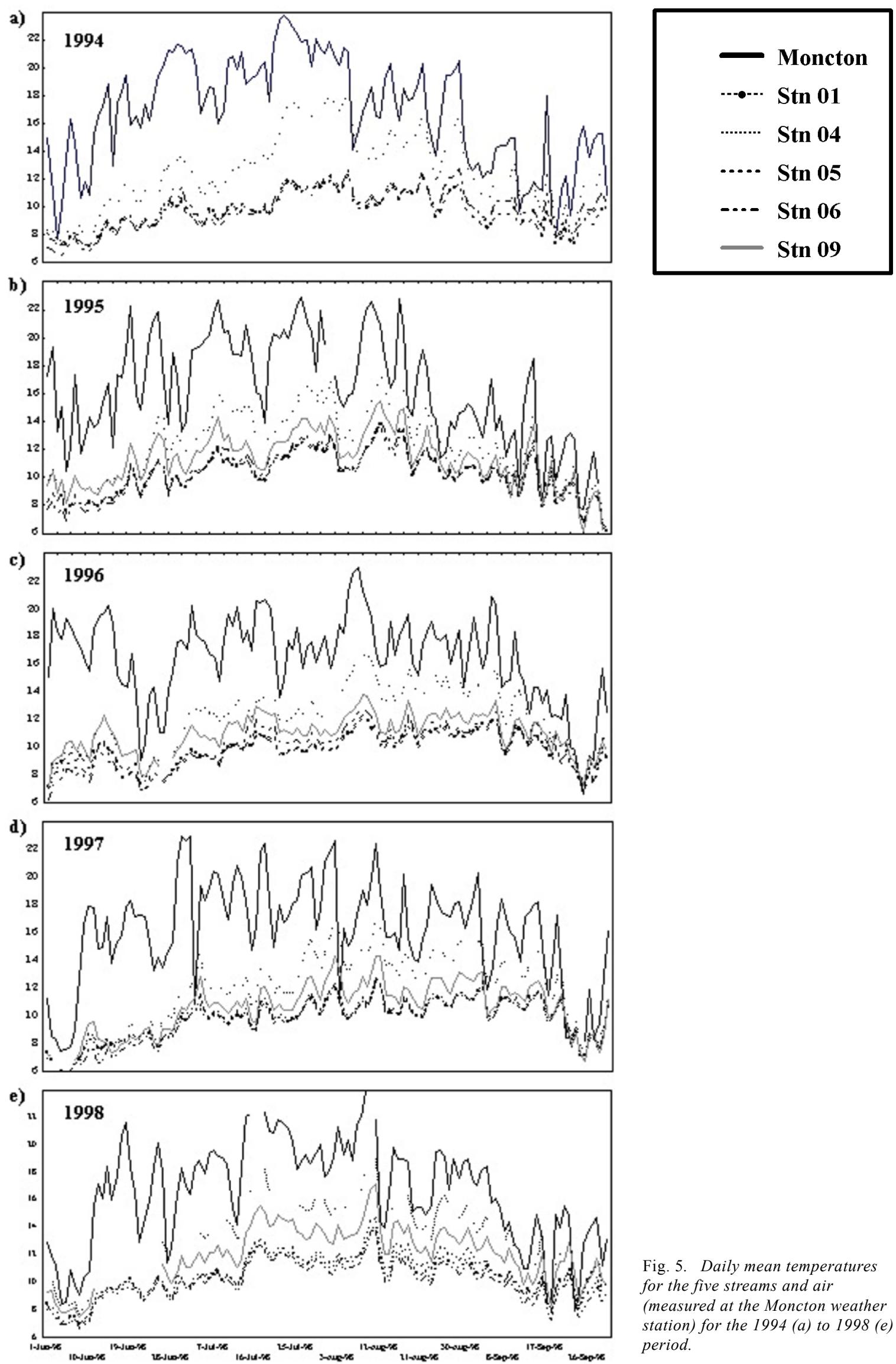

Fig. 5. Daily mean temperatures for the five streams and air (measured at the Moncton weather station) for the 1994 (a) to 1998 (e) period. 
Table 3. Modelled stream solar radiation, with and without harvesting effects, and mean hydraulic gradient (slope) along the entire stream network, including low-order, ephemeral streams and seepage points.

\begin{tabular}{lccc}
\hline \multicolumn{4}{c}{$\begin{array}{c}\text { One-day Mean Potential Solar Radiation } \\
\text { (MJ per stream cell) }\end{array}$} \\
$\begin{array}{l}\text { Without the } \\
\text { Stream }\end{array}$ & $\begin{array}{c}\text { With the } \\
\text { effect of harvesting }{ }^{f}\end{array}$ & $\begin{array}{c}\text { Mean hydraulic gradient } \\
\text { along stream channel }\left(^{\circ}\right)\end{array}$ \\
\hline $\mathbf{0 1}$ & 2722 & 2727 & 3.4 \\
$\mathbf{0 4}$ & 2745 & 2745 & 3.7 \\
$\mathbf{0 5}$ & 2710 & 2709 & 5.2 \\
$\mathbf{0 6}$ & 2723 & 2721 & 5.2 \\
$\mathbf{0 9}$ & 2729 & 2731 & 3.3 \\
${ }^{\mathrm{e}}$ under zero light attenuation & & \\
${ }^{\mathrm{f}}$ values are based on a weighted average taking into account the sunlight falling on the portion of the \\
catchment that was harvested and on the portion that was not harvested ${ }^{\mathrm{e}}$ during the 1994-1998 period. \\
\hline
\end{tabular}

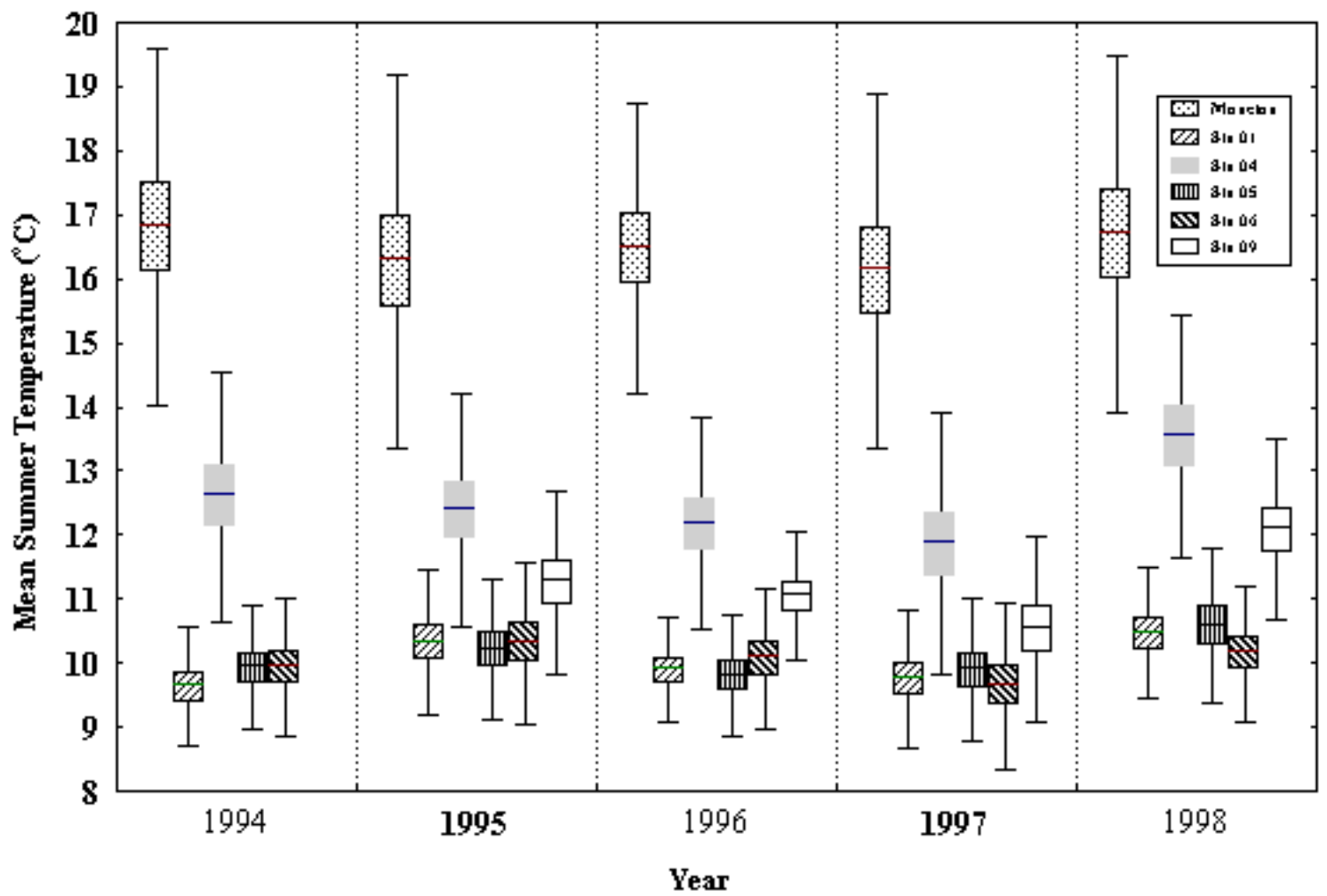

Fig. 6. Box plots of summer daily temperatures. The fine horizontal line in the centre of the box represents the mean; the upper and lower limits of the box correspond with two SE's from the mean, and the whiskers represent the nonoutlier range of the data, based on $1.5 x$ the Inter-Quartile Range. Harvesting years are identified in bold.

approximately 2733 MJ per exposed cell. Effective mean hydraulic slope in the deforested areas and for the entire sub-catchment was calculated to be approximately $2.3^{\circ}$ and $3.3^{\circ}$, respectively (Table 3 ). Also, because stream nine had one of the largest total surface area (Table 1), total solar influx to the stream may actually have been proportionally greater for this stream.

Both stream five and six had comparatively low overall calculated insolation inputs (i.e. 2710 and $2723 \mathrm{MJ}^{\text {cell- }}{ }^{-1}$ ) and high mean hydraulic gradients (Table 3). Under these 
special circumstances, instream temperatures for both streams should have been low over much of the summer period. Since stream five was on average three times as wide as stream six (Table 1), the low insolation input ( $-13 \mathrm{MJ}$ cell $\left.^{-1}\right)$ applied to the large surface area would not have necessarily resulted in cooler stream temperatures for that stream. In fact, from Fig. 5a, both streams have about the same daily mean temperatures during most of the summer in 1994. The insignificant amount of cutting in the upper portion of sub-catchment five (accounting for $<1 \%$ of the total land area and water flow; Table 2 and Fig. 2a) should had little to no measurable effect on stream temperatures downstream. Calculated local mean insolation in the cut areas was approximately $2747 \mathrm{MJ}$ per exposed cell. The low stream temperatures in stream one (Fig. 5a) were most probably a result of the low solar radiation input to the stream's sub-catchment (2722 MJ per stream cell; Table 3).

\section{POST-1995 HARVEST}

Figure 6 provides box plots of the summer daily mean temperatures [with the mean, $2 \times$ the standard error (SE), and non-outlier range indicated] for the five streams and that of the air over the five years. Summer mean stream temperatures in sub-catchments one, five and six ranged from 0.3 to $0.7^{\circ} \mathrm{C}$ higher in 1995 than in 1994. This represented a 4-8\% increase from 1994 temperatures. Line integrations of LanDSET-calculations of direct solar radiation within the harvested areas suggested that by cutting and by not leaving forest buffers, 2749 MJ per exposed stream cell was newly available to stream one (potentially contributing to a $0.7^{\circ} \mathrm{C}$ increase; see Fig. 5a), $2695 \mathrm{MJ}$ to stream five $\left(+0.3^{\circ} \mathrm{C}\right)$, and $2710 \mathrm{MJ}$ to stream six $\left(+0.4^{\circ} \mathrm{C}\right)$. Modelled insolation levels in upslope areas and observed summer mean temperature increases form a near-perfect linear expression (i.e. $y=0.0075 \times-19.822$ ), indicating that stream temperature changes observed in the 1995 noncontrol streams most likely occurred as a result of the level of deforestation and insolation in the upper catchment (Fig. $2 b)$. It was extremely unlikely that thinning of the forest buffer along stream one could have contributed solely to the temperature increase observed in that stream, knowing that streams five and six, despite not having their buffers thinned, responded in a similar way to cutting in their upper catchments (Table 2).

Statistical testing of the normalised daily temperatures indicated that changes in the normalised stream temperatures before- and after-harvest are significant for the 'non-control' streams (i.e. $\mathrm{p}<<0.05$; Table 4). In contrast, statistical testing of the actual dail mean termperatures for the 'control' stream (Table 4) indiicates no signigican change occurred in the mean temperatures over the same time period. This supports the contention that a statistically measurable change occurred in the summer temperatures in the non-control streams, and that the change was most likely a function of insolation and level of deforestation. During this same period, the control stream and the air both demonstrated decreases in their mean temperature $\left(\sim 0.2^{\circ} \mathrm{C}\right.$ and $0.5^{\circ} \mathrm{C}$, respectively; see Fig. 6 and Table 4). Apparently, upslope harvesting and insolation effects on the non-control streams were sufficiently strong to mitigate the weaker cooling effect of the atmosphere.

Table 4. Comparison of normalised summer mean stream temperatures between 1994 (pre-harvest) and 1995 (postharvest). The values in bracket are the non-normalised mean temperatures. Comparison for stream four (1995 control) is based on its actual mean temperatures.

\begin{tabular}{|c|c|c|c|c|c|}
\hline \multirow[t]{2}{*}{ Station } & \multicolumn{2}{|c|}{ Temperature Ratio } & \multirow[b]{2}{*}{ d. $f^{g}$} & \multirow[b]{2}{*}{ t-statistic ${ }^{h}$} & \multirow[b]{2}{*}{$p$-values } \\
\hline & 1994 (Pre-harvest) & 1995 (Post-harvest) & & & \\
\hline Moncton $^{\mathrm{i}}$ & $1.35(16.81)$ & $1.32(16.27)$ & 236 & 1.096 & $\mathrm{p}>0.250$ \\
\hline \# 01 & $0.78(9.62)$ & $0.84(10.32)$ & 235 & -7.632 & $\mathrm{p}<0.001$ \\
\hline \# 04 & $1.00(12.60)$ & $1.00(12.38)$ & 237 & 0.662 & $\mathrm{p}>0.500$ \\
\hline \# 05 & $0.80(9.93)$ & $0.83(10.20)$ & 224 & -3.283 & $\mathrm{p}<0.002$ \\
\hline \# 06 & $0.80(9.93)$ & $0.84(10.31)$ & 234 & -5.246 & $\mathrm{p}<0.001$ \\
\hline \# 09 & - & $0.91(11.25)$ & - & - & - \\
\hline \multicolumn{6}{|c|}{$\begin{array}{l}\mathrm{g} \text { denotes the degrees of freedom } \\
\text { h critical t-value for a two-tail test }= \pm 1.97 \\
\text { i air temperature }\left({ }^{\circ} \mathrm{C}\right)\end{array}$} \\
\hline
\end{tabular}


Table 5. Comparison of normalised summer mean stream temperatures between 1997 (pre-harvest) and 1998 (postharvest). The values in bracket are the non-normalised mean temperatures. Comparison for stream five (1998 control) is based on the actual mean temperatures.

\begin{tabular}{|c|c|c|c|c|c|}
\hline \multirow[t]{2}{*}{ Station } & \multicolumn{2}{|c|}{ Temperature Ratio } & \multirow[b]{2}{*}{ d.f..$^{g}$} & \multirow[b]{2}{*}{$t$-statistic ${ }^{h}$} & \multirow[b]{2}{*}{ p-values } \\
\hline & 1997 (Pre-harvest) & 1998 (Post-harvest) & & & \\
\hline Moncton $^{\mathrm{i}}$ & $1.63(16.12)$ & $1.57(16.69)$ & 242 & 1.613 & $\mathrm{p}>0.100$ \\
\hline \# 01 & $0.99(9.75)$ & $0.99(10.46)$ & 242 & -1.720 & $\mathrm{p}>0.050$ \\
\hline \# 04 & $1.18(11.85)$ & $1.27(13.72)$ & 242 & -7.220 & $\mathrm{p}<0.001$ \\
\hline \# 05 & $1.00(9.89)$ & $1.00(10.58)$ & 242 & -3.350 & $\mathrm{p}<0.001$ \\
\hline \# 06 & $0.96(9.65)$ & $0.96(10.15)$ & 242 & 0.200 & $\mathrm{p}>0.800$ \\
\hline \# 09 & $1.06(10.53)$ & $1.14(12.16)$ & 242 & -13.220 & $\mathrm{p}<0.001$ \\
\hline
\end{tabular}

During the 1995 to 1997 period, no significant temperature change occurred in the streams, except stream five. A debris dam upstream of station five broke in the spring of 1996 causing the Hydrolab probe to be submerged in deeper and cooler water for part of the summer (Fig. 6), until it was retrieved and relocated to a new, more representative stream location nearby.

\section{POST-1997 FALL HARVEST}

Total harvested area (pre-1994 +1997 harvests) in subcatchment four accounted for about $50 \%$ of the total upslope contributing area (Fig. 3). Most likely, an increase in mean temperature in stream four can be attributed to prevailing mid-summer warming conditions and to the amount of deforestation upslope. Compared to 1997 conditions, stream temperatures increased in the order of 1 to $2^{\circ} \mathrm{C}$ in 1998 (Fig. 6 ; Table 5), with the greatest increase occurring in streams four and nine, $+1.9^{\circ} \mathrm{C}$ and $1.6^{\circ} \mathrm{C}$, respectively $(\mathrm{p}<0.001$, for normalised values, with stream five as the control; Table 5), and least in streams one $\left(+0.71^{\circ} \mathrm{C}\right)$, five $\left(+0.69^{\circ} \mathrm{C}\right)$, and six $\left(+0.50^{\circ} \mathrm{C}\right)$ with a mean increase of about $0.63^{\circ} \mathrm{C}$. Note that the 1997-1998 change in the normalised values for streams one and six were not statistically significant ( $p>0.05$; Table 5), suggesting that the level of warming in streams one and six, when compared to the warming in the control stream (five), was generally the same (Fig. 6).

Stream temperature increase in streams one, five and six was approximately equal to the observed increase in the mean air temperature (i.e., $0.57^{\circ} \mathrm{C}$ ). Clearly, increased mean atmospheric warming, although not significant at the 5\% level (due to the high variability in the data; Fig. 6) when compared to 1997 conditions, contributed to a portion of the observed increase in stream temperatures. Accelerated warming in streams four and nine most likely happened in response to the combined effects of elevated insolation levels due to the streams' sub-catchment's position relative to the mid-summer sun (column 2, Table 3), the degree of upslope deforestation and insolation of exposed ground (column 3, Table 3), low hydraulic gradients within the harvested areas ( $\sim 3.6^{\circ}$ and $3.3^{\circ}$, respectively), atmospheric warming, and large stream surface area. Conceivably, the warming of streams five and nine from both atmospheric and radiative effects was probably enhanced on account of the streams' large energy-exchange surface area.

\section{FOREST BUFFERS}

No clear relationship existed between forest buffer strip width, as applied in this study, and the extent of stream warming observed at the monitoring stations. Stream four, with $60-\mathrm{m}$ forest buffer strips, consistently had the highest stream temperatures at the point of measurement (Fig. 5be), while streams five and six, with 30-m buffer strips, had some of the lowest recorded stream temperatures both before and after harvesting. Stream nine, also with $60-\mathrm{m}$ buffer strips, was consistently the second warmest stream (Fig. 6).

Work by Barton et al. (1985) found that for effective stream-temperature protection, buffer strips do not need to be any wider than several metres, depending on the buffer 
strips' height, canopy density and species composition. In practice, the harvesting of the upper catchment without providing adequate shade protection to the low-ordered streams $(<0.5 \mathrm{~m}$ wide), sub-surface water, and seepage points upslope of buffered streams diminishes the practical value of the forest buffer further downstream. Once the water in the upper catchment is warmed from direct insolation, forest buffers downstream have less value in the management of cold-water streams. Any cooling that occurs in buffered streams will be largely a function of the amount and entrance temperature of groundwater (baseflow) flowing into the stream.

\section{Conclusion}

Summer mean stream temperatures varied according to catchment-to-sun orientation, level of deforestation in the upper catchment, and slope conditions within the harvested areas. Modelled physical attributes of the catchments, such as land cover change, slope, aspect, one-day potential solar radiation, flow accumulation and stream-path integration (accumulation) of solar radiation and slopes, were vital in explaining differences in measured stream temperatures collected from five adjacent streams of near similar characteristics. Temperature increases at downstream measurement locations were shown to coincide with the amount of solar radiation and hydraulic gradients modelled for upslope harvest areas, where, for the most part, stream buffers were not required by regulation. No clear relationship existed between forest buffer strip width, as applied in this study, and the extent of stream warming.

Forest buffer strips left in place alongside the main stream branches to control stream warming had little or no effect when the stream water had already been warmed as a result of deforestation in the upper catchment. Clearly, unregulated harvesting (clear cutting) in upper catchments can have significant impact on water temperature and instream water quality further downstream. In practice, harvesting in the upper catchment of streams is appealing due to the low surface gradients and lack of visible surface water. Given stream sensitivity to harvesting in these areas, forest management strategies should focus on protecting these areas by ensuring that adequate forest cover is left on-site at all times. Forest buffer strips along streams $>0.5 \mathrm{~m}$ wide alone cannot be expected to provide all the protection that is required for effective stream-temperature and habitat management of intermediate- to large-size forest streams.

\section{Acknowledgements}

Support for this research was received from Environment Canada, Fundy Model Forest, Sussex, NB and Natural Sciences and Engineering Research Council of Canada in the form of an operating grant to CPB. The authors are grateful to Pat McCurry of the Evaluation Branch of EC in Ottawa who supplied the required field instrumentation. The authors extend their gratitude to Peter Delong and Guy Leger of the Meteorological Service Branch of EC in Fredericton, NB for their assistance in the field by maintaining and operating the water quality stations and in routine data collection. We also express our appreciation of the valuable suggestions for improving the manuscript provided by four external referees.

\section{References}

Barton, D.R., Taylor, W.D. and Biette, R.M., 1985. Dimensions of riparian buffer strips required to maintain trout habitat in southern Ontario streams. N. Amer. J. Fish. Manag., 5, 364-378.

Beschta, R.L. and Taylor, R.L., 1988. Stream temperature increases and landuse in a forested Oregon watershed. Water Resour. Bull., 24, 19-25.

Bourque, C.P.-A. and Gullison, J.J., 1998. A technique to predict hourly potential solar radiation and temperature for a mostly unmonitored area in the Cape Breton Highlands. Can. J. Soil Sci., 78, 409-420.

Bourque, C.P.-A., Meng, F.-R., Gullison, J.J. and Bridgland, J., 2000. Biophysical and potential vegetation growth surfaces for a small watershed in northern Cape Breton Island, Nova Scotia, Canada. Can. J. Forest Res., 30, 1179-1195.

Brown, G.W., 1980. Predicting temperatures on small streams. Water Resour. Res., 5, 68-75.

Brown, G.W. and Krygier, J.T., 1970. Effects of clearcutting on stream temperature. Water Resour. Res., 6, 1133-1140.

Chaisson, A.G., 1995. Aquatic habitat and fish description in small primary order streams: a case for protection and restoration. Proceedings of the $48^{\text {th }}$ CWRA Annual Conference, Managing the Water Environment, Fredericton, NB, Canada, 331-349.

Cluis, D.A., 1972. Relationship between stream water temperature and ambient air temperature. Nordic Hydrol., 3, 65-71.

Costa-Cabral, M.C. and Burges, S.J., 1994. Digital elevation model networks (DEMON): A model of flow over hillslopes for computation of contributing and dispersal areas. Water Resour. Res., 30, 1681-1692.

Davis, J.C., 1975. Minimal dissolved oxygen requirement of aquatic life with emphasis on Canadian species: a review. $J$. Fish. Res. Bd. Can., 32, 2295-2332.

Dozier, J., Bruno, J. and Downey, P., 1981. A faster solution to the horizon problem. Comput. Geosci., 7, 145-151.

Dubayah, R. and Rich, P.M., 1996. GIS-based Solar Radiation Modeling. In: GIS and Environmental Modeling: Progress and Research Issues, M. F. Goodchild, L.T. Steyaert and B.O. Parks, (Eds.). GIS World, Inc., Fort Collins, CO., U.S.A. 129-134.

Dubayah, R., Dozier, J. and Davis, F.W., 1990. Topographic distribution of clear-sky radiation over the Konza Prairie, Kansas. Water Resour. Res., 26, 679-690. 
Eckert, R., 1988. Mechanisms and adaptations. Animal Physiology. Freedman, New York, 683 pp.

Fahmy, S. and Colpitts, M., 1995. Soils of the Fundy Model Forest. Unpublished Rept., Fundy Model Forest-Agriculture and AgriFood Canada Res. Branch, CLBRR Contribution No. 95-96.

Fairfield, J. and Leymarie, P., 1991. Drainage networks from grid digital elevation models. Water Resour. Res., 27, 709-717.

Gallant, J.C. and Wilson, J.P., 1996. TAPES-G: A grid-based terrain analysis program for the environmental sciences. Comput. Geosci., 22, 713-722.

Hoar, W.S. and Randal, D.J., 1971. Environmental relation and behaviour. Fish Physiology, Vol. 6. Academic Press, New York, $559 \mathrm{pp}$.

Hondzo, M. and Stefan, H.S., 1994. Riverbed heat conduction prediction. Water Resour. Res., 30, 1503-1513.

Horne, A. J. and Goldman, C. R., 1994. Limnology, $2^{\text {nd }}$ edition. McGraw-Hill, Inc., 576 pp.

Huttener, P., Holopainen, A.L. and Hori, A., 1988. Effects of silvicultural measures on primary production in forest brooks. In: Symposium on the Hydrology of Wetlands in Temperate and Cold Regions, 6-8 June, Joensuu, Finland, 239-248.

Hydrolab, 1993. $\mathrm{H}_{2} \mathrm{O}$ Water Quality Multiprobe Operating Manual. Hydrolab Corporation, Austin, Texas, November.

Jenson, S.K., 1991. Applications of hydrologic information automatically extracted from digital elevation models. Hydrol. Process., 5, 31-44.

Krause, H., 1998. Buffer zone management. A component study of the Hayward Brook Watershed Project in the Fundy Model Forest, New Brunswick. Laboratory of Forest Soil and Environmental Quality. University of New Brunswick Technical Rept., 1.

LeBlanc, R.T., Brown, R.D. and FitzGibbon, J.E., 1997. Modeling the effects of land use change on the water temperature in unregulated urban streams. J. Environ. Manage., 49, 445-469.

Martin, C.W., Noel, D.S. and Federer, C.A., 1985. Clearcutting and the biogeochemistry of stream water in New England. $J$. Forest., 83, 686-689.

Mills, D., 1971. Salmon and trout: A resource, its ecology, conservation and management. Chaucer Press Limited, UK. 351 pp.

Molga, M., 1962. Agricultural meteorology. Part II: Outline of agrometeorological problems. Published for the National Science Foundation and the Department of Agriculture by Centralny Instytut Informacji Naukowo-Technicznej Ekonomicznej, Warszawa, Poland., 351 pp.

Moore, G.C., 1983. A report on the feasibility of harvesting timber within the buffer zones: A literature review. Unpublished Rept., Dept. of Nat. Resour., Fredericton, NB, Canada.

Moore, I.D., 1993. Hydrologic modeling and GIS. In: GIS and Environmental Modeling: Progress and Research Issues, M. F. Goodchild, L.T. Steyaert and B.O. Parks, (Eds.). GIS World, Inc., Fort Collins, CO., 143-148.
Moore, I.D., Norton, T.W. and Williams, J.E., 1993. Modelling environmental heterogeneity in forested landscapes. J. Hydrol., 150, 717-747.

NB Geographic Information Centre, 1997. Introductory workshop: NBGIC digital topographic database and digital terrain models, Version 2. Unpublished document, Govt of New Brunswick.

O'Callaghan, J.F. and Mark, D.M., 1984. The extraction of drainage networks from digital elevation data. Comput. Vis. Graphics Image Process., 28, 323-344.

Olivera, F., Reed, S. and Maidment, D. R., 1998. HEC-PrePro v. 2.0: An ArcView Pre-Processor for HEC's Hydrologic Modeling System. Center for Research in Water Resources, Univ. of Texas at Austin, Spring, 23 pp. \{http://www.ce.utexas.edu/ prof/ olivera/esri98/p400.htm $\}$

Plamondon, A.P., Gonzalez, A. and Thomassin, Y., 1982. Effects of logging quality: Comparison between two Quebec sites. In Proceedings of the Canadian Hydrology Symposium, 14-15 June, Fredericton, NB, 47-70.

Pomeroy, J., Kerekes, J. and Pollock, T., 1998. Pre-harvest characterizations of water chemistry and discharge for the Hayward-Holmes watersheds study in New Brunswick's Fundy Model Forest. Fundy Model Forest Tech. Note, Vol. 1, 19 pp.

Roth, N., Allen, J.D. and Erickson, D.L., 1996. Landscape influences on stream biotic integrity assessed at multiple spatial scales. Landscape Ecol., 11, 141-156.

Rowe, J.S., 1972. Forest Regions of Canada. Canadian Forest Service, Publication. 1300, 172 pp.

Schlosser, I.J., 1991. Stream fish ecology: A landscape perspective. Biosci., 41, 704-711.

Sinokrot, B.A. and Stefan, S.G., 1993. Stream temperature dynamics: measurements and modeling. Water Resour. Res., 29, 2299-2314.

Stewart, T. and Comeau, N., 1996. GO 4723: Stage en milieu de travail. Unpublished Rept., Dept. of Geography, Université de Moncton, NB, Canada.

Stott, T. and Marks, S., 2000. Effects of plantation forest clearfelling on stream temperatures in the Plynlimon experimental catchments, mid-Wales. Hydrol. Earth Syst. Sci., 4, 95-104.

Sugimoto, S., Nakamura, F. and Ito, A., 1997. Heat budget and statistical analysis of the relationship between stream temperature and riparian forest in the Toikanbetsu River Basin, northern Japan. J. Forest Res., 2, 103-107.

Swift, L.W. and Messer, J.B., 1971. Forest cutting raise temperatures of small streams in the south Appalachians. J. Soil Water Conserv., 26, 111-116.

van Groenwoud, H., 1980. Physical attributes of streams. In Nashwaak Experimental Watershed Project, Annual Rept. 197980, G.R. Powell, (Ed.), Faculty of Forestry, University of New Brunswick, Fredericton, NB, Canada, 22.

Weatherley, N.S. and Ormerod, S.J., 1990. Forests and the temperature of upland streams in Wales: A modelling exploration of the biological effects. Fresh. Biol., 24, 109-122. 
